\title{
FRAUD PENTAGON THEORY DALAM FINANCIAL STATEMENT FRAUD PADA PERUSAHAAN TERDAFTAR di JAKARTA ISLAMIC INDEX (JII) PERIODE 2014-2017 (Perspektif F-Score Model)
}

\author{
Faiz Rahman Siddiq ${ }^{1}$ \\ Agus Endrianto Suseno \\ Fakultas Ekonomi Universitas Setia Budi \\ faizrahmansiddiq@gmail.com \\ ae suseno@yahoo.com
}

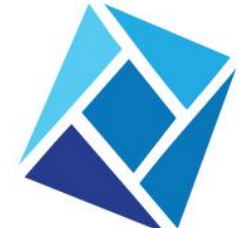

\section{Jurnal Nusantara}

Aplikasi Manajemen Bisnis

http://ojs.unpkediri.ac.id/index. php/manajemen/index

E-ISSN : 2528-0929

P-ISSN : 2549 - 5291

Diterima: 5 Agustus 2019

Revisi : 16 Agustus 2019

Disetujui: 28 September 2019 https://DOI

10.29407/nusamba.v4i2.13800

\section{Abstract}

Financial statement fraud biasa disebut dengan kecurangan laporan keuangan yang merupakan kesengajaan dalam melakukan kelalaian dan kesalahan ketika membuat laporan keuangan dengan penyajian yang tidak sesuai pada prinsip akuntansi berterima umum. Statement on Auditing Standards (SAS) No.99 menjelaskan tentang salah saji yang berhubungan dengan auditor dalam mengaudit laporan keuangan terhadap fraud diantaranya adalah (1) salah saji dari kesalahan suatu laporan keuangan merupakan suatu pengungkapan yang direncanakan guna menipu pengguna laporan keuangan, (2) penyalahgunaan aset atau istilah lain pencurian dan penggelapan sering dijadikan sebagai salah saji dalam laporan keuangan.

Fraud pentagon theory merupakan pengembangan dari teori fraud sebelumnya yaitu fraud triangle (Cressey, 1953) dan fraud diamond (Wolf and Hermanson,2004). Populasi penelitian ini adalah perusahaan yang tergabung dalam Indeks JII (Jakarta Islamic Index) pada tahun 2014-2017. Teknik pengambilan sampel dengan menggunakan metode purposive sampling. Metode analisis data yang digunakan dalam penelitian ini adalah analisis regresi linear berganda. Financial statement fraud dalam penelitian menggunakan perspektif F-Score Model. Hasil penelitian ini adalah pressure (Financial Stability, dan Financial Target), dan Opportunity (Nature of Industry) berpengaruh terhadap financial statement fraud. Sedangkan Pressure (External Pressure dan Personal Financial Need), Rationalization (Change in Auditor), Competence (Change of Director) dan Arrogance (Frequent Number of CEO's Picture dan Dualism Position) tidak berpengaruh terhadap financial statemnt fraud.

Kata kunci: financial statement fraud, F-Score Model, Fraud Pentagon Theory 


\section{PENDAHULUAN}

Laporan keuangan merupakan gambaran kinerja perusahaan yang menginformasikan pertumbuhan dan perkembangan perusahaan yang digunakan untuk manajemen perusahaan dan investor dalam proses pengambilan keputusan investasi. Standar Akuntansi Keuangan (SAK) mendefinisikan laporan keuangan merupakan bagian dari proses keseluruhan pelaporan keuangan yang terdiri dari laporan posisi keuangan, laporan laba rugi komprehensif, laporan perubahan ekuitas, laporan arus kas, catatan atas laporan keuangan dan laporan perubahan retrospektif. Laporan keuangan adalah bentuk hasil dari proses akuntansi yang memuat informasi histories (M. Sadeli, 2002:2). Laporan keuangan yang lengkap dinyatakan dalam PSAK 01 memiliki beberapa bagian dari suatu laporan keuangan yang terdiri dari: 1) Laporan Posisi Keuangan (neraca pada akhir periode); (2) Laporan Laba Rugi Komprehensif selama periode; (3) Laporan Perubahan Ekuitas selama periode; (4) Laporan Arus Kas selama periode; (5) Catatan atas Laporan Keuangan berisi informasi ringkasan kebijakan akuntansi penting dan informasi penjelasan lain. (6) Laporan Posisi Keuangan pada awal periode komparatif, ketika entitas menerapkan kebijakan akuntansi secara retrospektif, membuat penyajian kembali pos-pos laporan keuangan dan mereklasifikasi pos-pos dalam laporan keuangannya.

Laporan keuangan yang akan dijadikan sebagai tolok ukur dalam pengambilan keputusan oleh manajemen perusahaan dan investor sehingga oleh perusahaan terbuka (.Tbk) dalam penyajiannya dipublikasi di Bursa Efek Indonesia (BEI). Bursa Efek Indonesia (BEI) membagi laporan keuangan tersebut menjadi beberapa indeks saham, salah satunya adalah Indeks Saham Syariah Indonesia (ISSI) yang diluncurkan pada tanggal 12 Mei 2011. ISSI merupakan indikator dari kinerja pasar saham syariah Indonesia. Konstituen ISSI adalah seluruh saham syariah yang tercatat di BEI dan masuk ke dalam Daftar Efek Syariah (DES) yang diterbitkan oleh OJK. Artinya, BEI tidak melakukan seleksi saham syariah yang masuk ke dalam ISSI. Konstituen ISSI diseleksi ulang sebanyak dua kali dalam setahun, setiap bulan Mei dan November, mengikuti jadwal review DES. Oleh sebab itu, setiap periode seleksi, selalu ada saham syariah yang keluar atau masuk menjadi konstituen ISSI. Adapun daftar saham-saham konstituen indeks ISSI salah satunya adalah Jakarta Islamic Index (JII) yang merupakan indeks saham syariah yang pertama kali diluncurkan di pasar modal Indonesia pada tanggal 3 Juli 2000. Konstituen JII hanya terdiri dari 30 saham syariah paling likuid yang tercatat di BEI. Sama seperti ISSI, review saham syariah yang menjadi konstituen JII dilakukan sebanyak dua kali dalam setahun, Mei dan November, mengikuti jadwal review DES oleh OJK. Perkembangan saham syariah di BEI berkemb

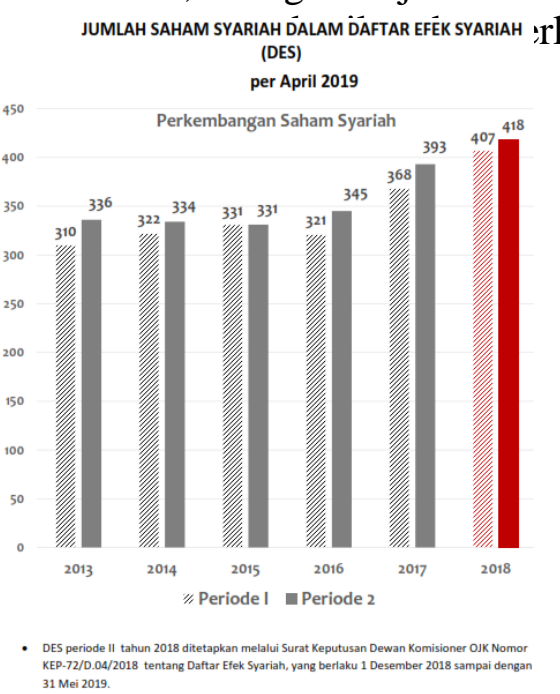

Gambar1.1.Perkembangan saham syariah.

Sumber : Direktorat Pasar Modal Syariah - Otoritas Jasa Keuangan

Kecurangan pelaporan keuangan merupakan suatu upaya yang dilakukan dengan sengaja oleh perusahaan untuk mengecoh dan menyesatkan para pengguna laporan keuangan, terutama investor dan 
kreditor, dengan menyajikan dan merekayasa nilai material dari laporan keuangan (Rezaee, 2014). Perusahaan menginginkan nilai saham tetap diminati oleh investor sehingga memotivasi untuk melakukan manipulasi keuntungan (earning manipulation). Kasus fraud akuntansi terjadi di perusahaan besar multinasional yaitu British Telecom pada unit lini nya yang berada di italia dan berdampak kepada Price Waterhouse Coopers (PWC) yang merupaan akuntan publik perusahaan tersebut. PwC gagal dalam melakukan pendeteksian fraud akuntansi tersebut, dan justru fraud dideteksi oleh pelapor pengaduan (whistleblower) dan diproses akuntansi forensik oleh KPMG. Modus yang dilakukan yaitu dengan melakukan inflasi (peningkatan) atas laba perusahaan dengan membesarkan penghasilan perusahaan dengan perpanjangan kontrak dan invoice secara fiktif dengan vendor dan selama beberapa tahun dengan metode tidak wajar melalui kerjasama koruptif dengan klien-klien perusahaan dan jasa keuangan. Fraud tersebut berdampak pada British Telecom harus menurunkan GBP530 juta dan memotong proyeksi arus kas selama tahun ini sebesar GBP500 juta untuk membayar utang-utang yang disembunyikan (tidak dilaporkan) sehingga British Telecom rugi membayar pajak penghasilan atas laba yang sebenarnya tak ada (Warta Ekonomi,2017).

Kasus fraud di Indonesia adalah Garuda Indonesia yang berdampak pada pengenaan sanksi oleh Kementerian Keuangan kepada Akuntan Publik (AP) Kasner Sirumapea Kantor Akuntan Publik (KAP) Tanubrata Sutanto Fahmi Bambang \& Rekan (Member of BDO Internasional). Laporan keuangan Garuda Indonesia untuk tahun buku 2018 membukukan laba bersih sebesar USD809,85 ribu atau setara Rp11,33 miliar (asumsi kurs Rp14.000 per dolar AS). Angka ini melonjak tajam dibanding 2017 yang menderita rugi USD216,5 juta sehingga menimbulkan polemik dengan asumsi bahwa laporan keuangan 2018 Garuda Indonesia tidak sesuai dengan Pernyataan Standar Akuntansi Keuangan (PSAK). Garuda Indonesia memasukan keuntungan dari PT Mahata Aero Teknologi terkait pemasangan wifi yang belum dibayarkan sehingga Garuda Indonesia dikenakan sanksi dari berbagai pihak. Auditor mendapatkan sanksi dari Menteri Keuangan Sri Mulyani dengan pembekuan izin selama 12 bulan. Selain itu, OJK juga akan mengenakan sanksi kepada jajaran Direksi dan Komisaris dari Garuda Indonesia dan masing-masing direksi harus membayar denda Rp100 juta. Garuda Indonesia mendapatkan sanksi lain juga dari BEI yaitu memberikan sanksi sebesar Rp250 juta kepada maskapai tersebut (Hartomo, 2019).

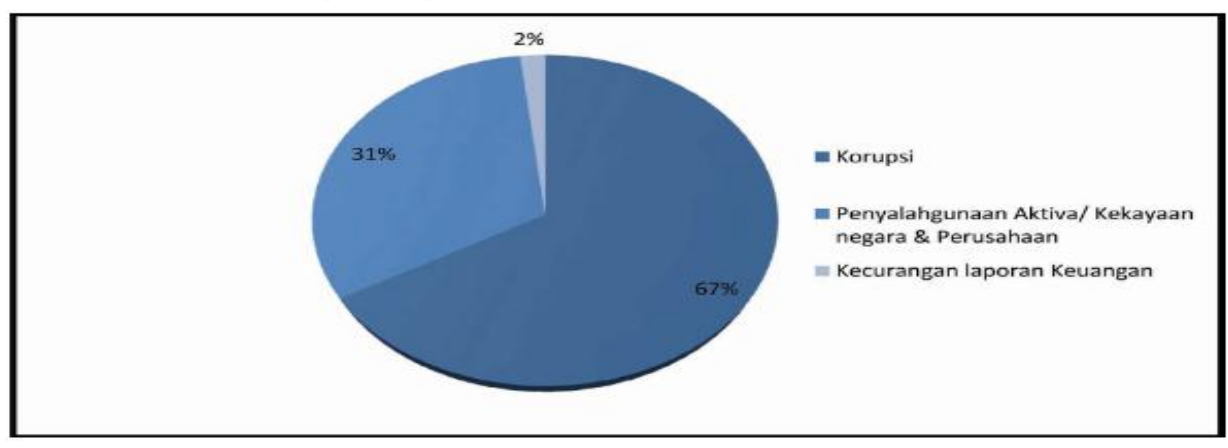

Gambar 1.2. Fraud yang paling banyak ditemukan di Indonesia. Sumber : ACFE Indonesia Chapter \#111

Albrecht dan Zimbelman (2009:7) mendefinisikan tentang beberapa fraud. Secara umum, fraud bisa dijelaskan sebagai istilah dan mencakup semua tindakan yang merupakan konsep kecerdasan manusia melalui individu, untuk mendapatkan manfaat dan keuntungan dari orang lain dengan penyajian yang salah. Tidak ada aturan yang paten untuk mendasari definisi fraud karena unsur di dalamnya adalah suatu penipuan kelicikan dan upaya dimana pihak lain dicurangi. Joseph Wells, dalam ACFE mendefinisikan fraud adalah suatu bentuk perbuatan yang disengaja guna mengambil keuntungan dengan menyalahgunakan posisi/ hak milik atau mencuri aset/sumber daya dalam 
organisasi. Statements of Auditing Standard No.99 mendefinisikan bahwa fraud merupakan suatu perbuatan yang disengaja dengan tujuan untuk menciptakan salah saji materiil pada laporan keuangan subjek audit. Albrechtzet al. (2011), menjelaskan beberapa elemen penting pada fraud yaitu (1) Representation (penyajian); (2) About a Material Point (menyangkut hal-hal yang material); (3) Which is false (yang salah); (4) And intentionally or recklessly so (dan dilakukan dengan sengaja); (5) Which is believed (yang dipercayai); (6) And acted upon by the victim (dan dilakukan pada korban); (7) To the victim's damage (untuk kerugian korbannya).

Faktor-faktor risiko keuangan mengalami perkembangan dari teori cressey (1953) ke teori Crowe (2011). Fraud triangle Cressey's theory (1953) mengalami pengembangan teori oleh Wolfe dan Hermanson (2004), dengan menambahkan satu faktor capability yang berpengaruh signifikan terhadap fraud dan menjadi teori baru yaitu fraud diamond. Elemen fraud diamond adalah pressure, opportunity, rationalization, dan capability. Fraud Diamond theory dikembangkan lagi oleh Crowe (2011) menjadi Crowe's Fraud Pentagon Model. Teori ini digunakan untuk deteksi financial statement fraud pada perusahaan. Fraud risk factor fraud pentagon adalah pressure, opportunity, rationalization, competence dan arrogance. Fraud Pentagon Theory merupakan pengembangan dari fraud triangle theory oleh Cressey (1953), kemudian fraud diamond theory yang dikembangkan oleh Wolf \& hermanson (2004). Fraud risk factor dalam teori fraud pentagon adalah (1) Pressure (tekanan) yaitu adanya motivasi untuk melakukan dan menyembunyikan tindakan fraud. (2) Opportunity (peluang) yaitu terburuknya kesempatan dikarenakan pelaku percaya bahwa aktivitas mereka tidak akan terdeteksi (Sukirman dan Sari, 2013). (3) Rationalization (rasionalisasi) yaitu suatu sikap pembenaran terhadap tindakan fraud yang telah dilakukan. (4) Competence/Capability (kompetensi) yaitu keahlian karyawan untuk mengabaikan kontrol internal, mengembangkan strategi penyembunyian, dan mengamati kondisi sosial untuk memenuhi kepentingan pribadinya (Crowe,2011). (5) Arrogance (arogansi) merupakan sifat superioritas atas hak yang dimiliki dan merasa bahwa pengendalian internal dan kebijakan perusahaan tidak berlaku untuk dirinya (Crowe, 2011).

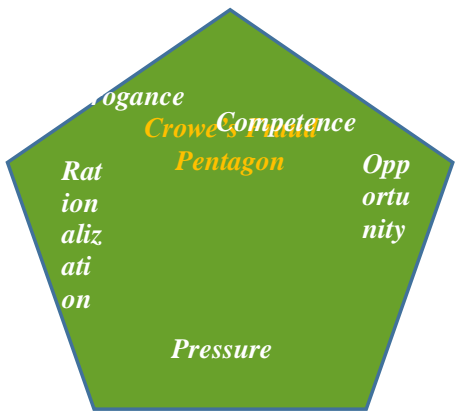

Gambar 1.3. Fraud pentagon theory by Crowe, (2011)

Kecurangan terjadi karena adanya perbedaan kepentingan antara principal dan agent. Agency Theory merupakan suatu hubungan antara principal (pemegang saham) dengan agent (manajemen). Dalam teori ini yang dimaksud principal adalah investor, sedangkan agent adalah manajemen perusahaan (manajer, staff, dan karyawan). Teori Keagenan merupakan suatu acuan bisnis dan merupakan sebagai landasan dasar dalam perusahaan. Teori tersebut memberikan gambaran tentang adanya korelasi atau hubungan shareholders (pemegang saham) atau biasa disebut dengan principal dengan agent (manajemen) pada nexus of contract atau perjanjian kerja sama (Jensen dan Meckling, 1976)

Penelitian ini merupakan pengembangan dari hasil penelitian terdahulu yang inkonsisten dan modifikasi dari penelitian Yesiariani (2016) dan Tessa dan Harto (2016). Perbedaan penelitian ini dengan penelitian sebelumnya adalah penelitian ini akan menganalisis fraud pentagon theory dalam mendeteksi financial statement fraud dengan menggunakan F-Score Model, populasi yang digunakan menggunakan periode yang lebih panjang yaitu perusahaan yang tergabung di Indeks JII (Jakarta 
Islamic Index) periode tahun 2014-2017, serta dengan menambahkan proxy pada variabel arrogance berupa dualism position

\section{METODE PENELITIAN}

Penelitian ini menggunakan metode kuantitatif. Metode tersebut berhubungan dengan pengumpulan data, analisis data, serta interprestasi analisis memperoleh informasi yang bertujuan menarik kesimpulan dan membuat kesimpulan (Tuban,1976). Terdapat 10 (sepuluh) variabel yang merupakan 1 (satu) variabel dependen dan 9 (sembilan) variabel independen.Teknik pengumpulan data dalam penelitian ini menggunakan metode dokumentasi (membaca, mengamati, mencatat) serta mempelajari uraian buku-buku, jurnal-jurnal akuntansi dan bisnis, menggunakan data Indonesian Capital Market Directory (ICMD), Bursa Efek Indonesia (www.idx.co.id) atau situs masing-masing perusahaan sampel. Sampel pada penelitian ini diperoleh dengan menggunakan purposive sampling method.

Variabel dependen yang digunakan dalam penelitian ini adalah kecurangan laporan keuangan. Penelitian ini mendeteksi financial statement fraud menggunakan fraud score model atau biasa disebut F-score, dimana model tersebut dikembangkan oleh (Dechow et. al., 2007). Model F-Score merupakan penjumlahan dari dua komponen variabel dalam fraud score model, yaitu kualitas akrual dan kinerja keuangan (skousen, 2009), dapat digambarkan dalam persamaan berikut: F-Score = Accrual Quality + Financial Performance. Kualitas akrual yang diproksikan dengan RSST accrual (Richardson, Sloan, Soliman dan Tuna, 2005) dan financial performance yang diproksikan dengan perubahan dalam akun piutang, perubahan dalam akun penjualan tunai dan perubahan pada pendapatan sebelum bunga dan pajak. Perusahaan dapat diprediksi melakukan kecurangan terhadap laporan keuangan menggunakan fraud score model tersebut.

Keterangan:

$$
\text { RSST Accrual }=\frac{(\Delta W C+\Delta N C O+\triangle F I N)}{\text { Average Total Asset }}
$$

WC $($ Working Capital $)=($ CurrentAssets - Current Liability $)$

NCO (Non Current Operating Accrual $)=($ Total Assets - Current Assets - Investment and Advances $)$

$$
\text { - (Total Liabilities - Current Liabilities - Long Term Debt) }
$$

FIN $($ Financial Accrual $)=$ Total Investment - Total Liabilities

ATS $($ Average Total Assets $)=\left(\frac{\text { Beginning Total Asset }+ \text { End Total Asset }}{2}\right)$

Financial Performance $=$ change in receivable + change in inventories + change in cash sales + change in earnings

Keterangan:

$$
\begin{aligned}
& \text { Change in Receivable: } \frac{\Delta \text { Receivable }}{\text { Average Total Assei }} \\
& \text { Change in Inventory: } \frac{\Delta \text { Inventory }}{\text { Average Total Awrei }} \\
& \text { Changes in cash sales: } \frac{\Delta \text { Sales }}{\text { Sales }(t)}-\frac{\Delta \text { Receivable }}{\text { Receivable }(t)} \\
& \text { Changes in Earnings: } \frac{\text { Earnings (t) }}{\text { Average TotalAssets (t) }}-\frac{\text { Earnings (t-1) }}{\text { Average TotalAssets (T-1) }}
\end{aligned}
$$


Tabel 2.1 variabel independen dan pengukurannya.

\begin{tabular}{|c|c|c|}
\hline $\begin{array}{c}\text { Faktor Risiko } \\
\text { Fraud }\end{array}$ & Kategori & Pengukuran \\
\hline \multirow[t]{4}{*}{ Pressure } & Financial Stability & ACHANGE $=\frac{(\text { Total Aset } t-\text { Total Aset }(t-1))}{\text { Total Aset } t-1}$ \\
\hline & External Pressure & $L E V=\frac{\text { Kewajiban }}{\text { Total Assel }}$ \\
\hline & $\begin{array}{l}\text { Personal Financial } \\
\text { Need }\end{array}$ & OSHIP $=\frac{\text { Total saham yang dimiliti oleh orang dalam }}{\text { Total saham bias a yang beredar }}$ \\
\hline & Financial Target & ROA $=\frac{\text { Net Income }}{\text { Total Asset }}$ \\
\hline Opportunity & Nature Of Industry & RECENVABLE $=\frac{\text { Receñable } t}{\text { Sales } t}-\frac{\text { Receñable } t-1}{\text { Sales } t-1}$ \\
\hline Rationalization & Change Of Director & $\begin{array}{l}\text { variabel dummy, apabila terdapat pergantian Kantor } \\
\text { Akuntan Publik selama periode } 2014-2015 \text { maka diberi } \\
\text { kode } 2 \text {, Jika sebaliknya diberi kode } 1 \\
\text { variabel dummy, kode } 2 \text { jika terdapat pergantian direksi } \\
\text { dalam perusahaan, kode } 1 \text { jika sebaliknya }\end{array}$ \\
\hline \multirow[t]{2}{*}{ Arrogance } & $\begin{array}{l}\text { Frequent number of } \\
\text { CEO's picture }\end{array}$ & $\begin{array}{l}\text { Jumlah display picture ataupun profil, prestasi, foto, } \\
\text { ataupun informasi lainnya mengenai track of record } \\
\text { CEO yang dipaparkan secara berulang-ulang dalam } \\
\text { laporan tahunan perusahaan. }\end{array}$ \\
\hline & Dualism Position & $\begin{array}{l}\text { Dualism position merupakan keadaan di mana seorang } \\
\text { direksi memiliki jabatan lain baik di dalam maupun luar } \\
\text { perusahaan. Dalam penelitian ini dualisme jabatan } \\
\text { diukur dengan melihat CEO atau presiden yang memiliki } \\
\text { jabatan dualisme dalam perusahaan sebagai variabel } \\
\text { indikator dengan dummy nilai } 2 \text { jika ada dan } 1 \text { jika tidak } \\
\text { ada. }\end{array}$ \\
\hline
\end{tabular}

Dalam penelitian ini alat analisis yang digunakan untuk menguji hipotesis adalah regresi berganda. Regresi berganda yaitu metode statistik untuk menguji pengaruh antara beberapa variabel bebas terhadap satu variabel terikat, dalam penelitian ini terdapat model penelitian sebagai berikut:

$$
\begin{aligned}
& \text { F-SCORE }=\beta 0+\beta 1 \text { ACHANGE + } 32 L E V+\beta 3 O S H I P+\beta 4 R O A+ \\
& \beta 5 \text { RECEIVABLE + } \beta 6 C P A+\beta 7 D C H A N G E+\beta 8 C E O P I C+ \\
& \text { B9DUALISM }+\varepsilon
\end{aligned}
$$

\begin{tabular}{|c|c|}
\hline$\beta 0$ & $=$ Koefisien regresi konstanta \\
\hline$\beta 1,2,3,4,5,6,7,8,9$ & $=$ Koefisien regresi masing-masing proksi \\
\hline$F-S C O R E$ & $=$ Financial Statement Fraud \\
\hline ACHANGE & $=$ Rasio perubahan total aset tahun 2014-2015 \\
\hline$L E V$ & $=$ Rasio total kewajiban per total aset \\
\hline OSHIP & $=$ Rasio kepemilikan saham oleh orang dalam \\
\hline$R O A$ & $=$ Return on assets \\
\hline RECEIVABLE & $=$ Rasio perubahan piutang usaha \\
\hline$C P A$ & $=$ Pergantian auditor independen \\
\hline DCHANGE & $=$ Pergantian direksi \\
\hline CEOPIC & $=$ Jumlah profile CEO dalam laporan keuangan \\
\hline DUALISM & $\begin{aligned}= & \text { Jajaran CEO dan presiden yang memiliki jabatan } \\
& \text { dualisme }\end{aligned}$ \\
\hline & $=$ error \\
\hline
\end{tabular}

Keterangan: 


\section{HASIL DAN PEMBAHASAN}

\section{Deskripsi Data Penelitian}

Penelitian ini menggunakan data sekunder berupa laporan keuangan perusahaan yang tergabung dalam indeks JII yang diperoleh dari laporan keuangan atau annual report perusahaan, Indonesia Capital Market Directory (ICMD), website resmi BEI (www.idx.co.id), serta situs masingmasing perusahaan sampel. Populasi dalam penelitian ini merupakan seluruh perusahaan yang tergabung dalam indeks JII selama periode 2014-2017 dengan jumlah sebanyak 120 perusahaan. Pemilihan sampel dalam penelitian ini menggunakan teknik purposive sampling dengan kriteria tertentu. Berdasarkan kriteria yang ditetapkan sebelumnya maka diperoleh jumlah sampel sebesar 82 perusahaan indeks JII .

Tabel 3.1

Kriteria Pengambilan Sampel Penelitian

\begin{tabular}{clc}
\hline No & \multicolumn{1}{c}{ Keterangan } & Jumlah \\
\hline 1 & Perusahaan yang tergabung dalam indeks JII selama & 120 \\
& periode 2014-2017 & \\
2 & Perusahaan yang datanya tidak lengkap & $(13)$ \\
3 & Data Outlier & $(25)$ \\
Jumlah Sampel & $\mathbf{8 2}$ \\
\hline
\end{tabular}

Sumber: Hasil Analisis

Berdasarkan tabel tersebut terdapat outlier sejumlah 25 untuk indeks JII. Outlier adalah kasus atau data yang memiliki karakteristik unik yang terlihat sangat berbeda jauh dari observasi-observasi lainnya dan muncul dalam bentuk nilai ekstrim baik untuk sebuah variabel tunggal atau variabel kombinasi. Uji outlier dapat dilakukan dengan cara menambah data, mentransformasi data, atau dengan mengurangi data yang bersifat ekstrim. Cara mendeteksi outlier bisa dilakukan dengan metode casewise diagnostics atau z-score (Ghozali, 2009). Pada saat dilakukan uji asumsi klasik ditemukan bahwa terdapat beberapa variabel penelitian yang tidak berdistribusi normal dan terkena heteroskedastisitas. Maka dari itu peneliti memutuskan untuk melakukan pengujian outlier. Dalam penelitian ini pengujian outlier menggunakan metode casewise diagnostics yaitu dengan menghapus nilai standar deviasi lebih dari 3. Setelah dilakukan uji outlier, jumlah data indeks JII yang semula berjumlah 107 berkurang menjadi 82, dan jumlah ini yang dijadikan sampel penelitian.

\section{Uji Normalitas}

Hasil pengujian normalitas data dengan menggunakan One Sample Kolmogorov-Smirnov ( $K$ S) Test. Hasil uji normalitas memiliki p-value lebih dari 0.05 yaitu sebesar 0.178 , berarti dapat disimpulkan bahwa semua data berdistribusi normal.

Tabel 3.2

Uji Normalitas Indeks JII

\begin{tabular}{lcc}
\hline Keterangan & P-Value & Simpulan \\
\hline Normalitas & 0,178 & Berdistribusi Normal \\
\hline Sumber: Hasil Analisis & &
\end{tabular}

\section{Uji Koefisien Determinasi $\left(\mathbf{R}^{\mathbf{2}}\right)$}

Besarnya angka koefisien determinasi ( $\mathrm{R}$ square) adalah 0,346 atau sama dengan 34,6\%. Angka tersebut menunjukkan bahwa variabel independent (financial stability, external pressure, personal financial need, financial target, nature of industry, rationalization, competence, frequent number of CEO's picture, dualism position) secara simultan (bersama-sama) berpengaruh terhadap variabel dependent (financial statement fraud.) sebesar 34,6\%. Sedangkan sisanya $65.4 \%$ dipengaruhi oleh variabel lain diluar persamaan regresi ini atau variabel yang tidak diteliti. 


\begin{tabular}{cccc} 
& \multicolumn{2}{c}{ Tabel 3.3 } \\
& \multicolumn{2}{c}{ Uji koefisien determinasi $\left(\mathbf{R}^{\mathbf{2}}\right)$} \\
\hline Model & $\mathbf{R}$ & R Square & Adjusted R Square \\
\hline 1 & .588 & .346 & .264 \\
\hline
\end{tabular}

Sumber : Hasil Analisis

\section{Pengujian Koefisien Regresi Simultan (Uji-F)}

Hasil uji-F diperoleh nilai $\mathrm{F}_{\text {hitung }}>\mathrm{F}_{\text {tabel }}$ sebesar 4,223 (4,223 > 2,01) dengan signifikansi yang kurang dari $\alpha(0,000<0,05)$ hal ini berarti bahwa variabel independen financial stability, external pressure, personal financial need, financial target, nature of Industry, rationalization, competence, frequent number of CEO's picture, dualism position perusahaan berpengaruh secara simultan terhadap variabel dependent financial statement fraud. Model penelitian adalah fit dengan data atau robust.

Tabel 3.4

Hasil Uji-F

\begin{tabular}{lcc}
\hline Keterangan & F & Sig \\
\hline Uji F & 4,223 & 0,000 \\
\hline
\end{tabular}

Sumber : Hasil Analisis

\section{Pengujian Koefisien Regresi Parsial (Uji-t)}

1. Hasil Uji Hipotesis Kesatu (a). Hipotesis kesatu (a) bertujuan untuk menguji apakah financial stability berpengaruh terhadap financial statement fraud. Hasil penelitian variabel financial stability memiliki tingkat signifikansi sebesar 0,000 lebih kecil dari $\alpha$ sebesar 0,05 atau $(\mathrm{p}>0,05)$. Hasil regresi memberi bukti secara empiris bahwa financial stability berpengaruh terhadap financial statement fraud pada perusahaan yang tergabung dalam indeks JII 2014-2017.

2. Hasil Uji Hipotesis Kesatu (b). Hipotesis kesatu (b) bertujuan untuk menguji apakah external pressure berpengaruh terhadap financial statement fraud. Hasil penelitian variabel external pressure memiliki tingkat signifikansi sebesar 0,294lebih besar dari $\alpha$ sebesar 0,05 atau $(\mathrm{p}>0,05)$. Hasil regresi memberi bukti secara empiris bahwa external pressure tidak berpengaruh terhadap financial statement fraud pada perusahaan yang tergabung dalam indeks JII 2014-2017.

3. Hasil Uji Hipotesis Kesatu (c). Hipotesis kesatu (c) bertujuan untuk menguji apakah personal financial need berpengaruh terhadap financial statement fraud. Hasil penelitian variabel personal financial need memiliki tingkat signifikansi sebesar 0,498 lebih besar dari $\alpha$ sebesar 0,05 atau (p > 0,05). Hasil regresi memberi bukti secara empiris bahwa personal financial need tidak berpengaruh terhadap financial statement fraud pada perusahaan yang tergabung dalam indeks JII 2014-2017.

4. Hasil Uji Hipotesis Kesatu (d). Hipotesis kesatu (d) bertujuan untuk menguji apakah financial target berpengaruh terhadap financial statement fraud. Hasil penelitian variabel financial target memiliki tingkat signifikansi sebesar 0,039 lebih kecil dari $\alpha$ sebesar 0,05 atau ( $>>0,05)$. Hasil regresi memberi bukti secara empiris bahwa financial target berpengaruh terhadap financial statement fraud pada perusahaan yang tergabung dalam indeks JII 2014-2017.

5. Hasil Uji Hipotesis Kedua. Hipotesis kedua bertujuan untuk menguji apakah nature of Industry berpengaruh terhadap financial statement fraud. Hasil penelitian variabel nature of Industry memiliki tingkat signifikansi sebesar 0,000 lebih kecil dari $\alpha$ sebesar 0,05 atau $(\mathrm{p}>0,05)$. Hasil regresi memberi bukti secara empiris bahwa nature of Industry berpengaruh terhadap financial statement fraud pada perusahaan yang tergabung dalam indeks JII 2014-2017.

6. Hasil Uji Hipotesis Ketiga. Hipotesis ketiga bertujuan untuk menguji apakah rationalization berpengaruh terhadap financial statement fraud. Hasil penelitian variabel rationalization memiliki tingkat signifikansi sebesar 0,452 lebih besar dari $\alpha$ sebesar 0,05 atau $(\mathrm{P}>0,05)$. Hasil regresi 
memberi bukti secara empiris bahwa rationalization tidak berpengaruh terhadap financial statement fraud pada perusahaan yang tergabung dalam indeks JII 2014-2017.

7. Hasil Uji Hipotesis Keempat. Hipotesis keempat bertujuan untuk menguji apakah competence berpengaruh terhadap financial statement fraud. Hasil penelitian variabel competence memiliki tingkat signifikansi sebesar 0,695 lebih besar dari $\alpha$ sebesar 0,05 atau ( $>>0,05)$. Hasil regresi memberi bukti secara empiris bahwa competence tidak berpengaruh terhadap financial statement fraud pada perusahaan yang tergabung dalam indeks JII 2014-2017.

8. Hasil Uji Hipotesis Kelima (a). Hipotesis kelima (a) bertujuan untuk menguji apakah frequent number of CEO's picture berpengaruh terhadap financial statement fraud. Hasil penelitian variabel frequent number of CEO's picture memiliki tingkat signifikansi sebesar 0,882 lebih besar dari $\alpha$ sebesar 0,05 atau ( $\mathrm{p}>0,05)$. Hasil regresi memberi bukti secara empiris bahwa frequent number of CEO's picture tidak berpengaruh terhadap financial statement fraud pada perusahaan yang tergabung dalam indeks JII 2014-2017.

9. Hasil Uji Hipotesis Kelima (b). Hipotesis kelima (b) bertujuan untuk menguji apakah dualism position berpengaruh terhadap financial statement fraud. Hasil penelitian variabel dualism position memiliki tingkat signifikansi sebesar 0,669 lebih besar dari $\alpha$ sebesar 0,05 atau $(\mathrm{p}>0,05)$. Hasil regresi memberi bukti secara empiris bahwa dualism position tidak berpengaruh terhadap financial statement fraud pada perusahaan yang tergabung dalam indeks JII 2014-2017.

Tabel 3.5

\begin{tabular}{|c|c|c|c|c|}
\hline \multicolumn{5}{|c|}{ Hasil Uji -t } \\
\hline Variabel & Koefisien & $\mathbf{t}_{\text {hitung }}$ & Sig. & Keterangan \\
\hline Konstanta & $-0,198$ &,- 520 & 0,604 & \\
\hline ACHANGE & 0,132 & 4,466 & 0,000 & $\mathrm{H}_{1 \mathrm{a}}$ diterima \\
\hline LEVERAGE & 0,291 & 1,058 & 0,294 & $\mathrm{H}_{1 \mathrm{~b}}$ ditolak \\
\hline OSHIP & 1,725 & 0,682 & 0,498 & $\mathrm{H}_{1 \mathrm{c}}$ ditolak \\
\hline$R O A$ & 0,970 & 2,107 & 0,039 & $\mathrm{H}_{1 \mathrm{~d}}$ diterima \\
\hline RECEIVABLE & $-2,296$ & $\begin{array}{c}- \\
3,911\end{array}$ & 0,000 & $\mathrm{H}_{2}$ diterima \\
\hline$C P A$ & $-0,143$ & 0,756 & 0,452 & $\mathrm{H}_{3}$ ditolak \\
\hline DCHANGE & 0,034 & 0,393 & 0,695 & $\mathrm{H}_{4}$ ditolak \\
\hline СЕОРIC & $-0,009$ & $\begin{array}{c}- \\
0,149\end{array}$ & 0,882 & $\mathrm{H}_{5 \mathrm{a}}$ ditolak \\
\hline DUALISM & 0,070 & 0,429 & 0,669 & $\mathrm{H}_{5 \mathrm{~b}}$ ditolak \\
\hline
\end{tabular}

Sumber : Hasil Analisis

\section{PENUTUP}

\section{Kesimpulan}

Kesimpulan hasil penelitian adalah Pressure pada financial stability (ACHANGE) dan financial target (ROA) berpengaruh dalam mendeteksi financial statement fraud pada perusahaan yang terdaftar di saham syariah Jakarta Islamic Indek (JII). Faktor risiko fraud pressure pada external pressure (LEV) dan personal financial need (OSHIP); opportunity pada nature of industry (RECEIVABLE); Rationalization pada perubahan auditor (change in auditor); Competence pada perubahan direksi (change of director) dan arrogance pada frequent number of CEO's picture dan dualism position tidak berpengaruh dalam mendeteksi financial statement fraud di saham syariah Jakarta Islamic Index (JII) 


\section{DAFTAR PUSTAKA}

Achyani, et.al.,2015. “Pengaruh Praktik Corporate Governance Terhadap Nilai Perusahaan Dengan Dengan Manajemen Laba Sebagai Variabel Intervening (Studi Kasus Pada Perusahaan Publik Di Indonesia)". ISSN 2407-9189. Univesity Research Colloquium .

AICPA, SAS No.99. 2002."Consideration of Fraud in a Financial Statement Audit ".AICPA. New York.

Albrecht, W. S. 2002. “Fraud Examination”. Mason, OH: Thomson SouthWestern,United States of America.

Association of Certified Fraud Examiners. 2016. "Report to the nation on occupational fraud and abuse (2016 global fraud study)". Retrieved from www.acfe.com/rttn/rttn-2016.pdf.

Association of Certified Fraud Examiners Indonesia Chapter \#111

Cressey, D. R. (1953). “Other People's Money”. Montclair, NJ: Patterson Smith, pp.1- 300.

Crowe, H. (2011). Why the Fraud Triangle is No Longer Enough. Retrieved from www.crowehorwath.com

Crowe Horwarth. 2012. "The Mind Behind The Fraudsters Crime :Key Behavioral and Environmental Element"

Dechow, P. M., Sloan, R. G., and Sweeney, A. P. 1996. "Causes and Consequences Of Earnings Manipulaton: An Analysis of Firms Subject to Enforcement Actions by the SEC". Contemporary Accounting Research. 13.1: 1-36.

Ghozali, Imam. 2013. "Aplikasi Analisis Multivariate dengan Program IBM SPSS 21". Semarang: BP UNDIP.

Hartomo,Giri. 2019. "Kronologi Kasus Laporan Keuangan Garuda Indonesia hingga Kena Sanksi”. Okefinance.

Hassink, Harold., Roger Meuwissen dan Laury Bollen. 2010. "Fraud detection, redress and reporting by auditors". Managerial Auditing Journal Vol. 25 No. 9, 2010 pp. 861- 881.

Koroy,Tri Ramaraya.2008. "Pendeteksian Kecurangan (Fraud) Laporan Keuangan Umi Narimawati dkk. 2010". Penulisan Karya Ilmiah:Panduan Awal Menyusun Skripsi dan Tugas Akhir. Jakarta: Penerbit Genesis

Loebbecke, J.K. , M.M. Eining dan J.J Willingham. 1989. Auditors Experience with Irregularities : Frequency Nature and Detectability. Auditing : A Journal of Practice \& Theory, 9 $: 1-28$.

Lou, Y.-I., \& Wang, M.-L. 2009. "Fraud Risk Factor Of The Fraud Triangle Assessing The Likelihood Of Fraudulent Financial Reporting”. Journal of Business \& Economics Research, 7(2), 61-78.

Priantara, Diaz.2019. "Ketika Skandal Fraud Akuntansi Menerpa British Telecom dan PwC”. Warta Ekonomi

Sihombing, Kennedy Samuel, \& Shiddiq Nur Rahardjo. 2014. "Analisis Fraud Diamond dalam Mendeteksi Financial Statement Fraud" : Studi Empiris Pada Perusahaan Manufaktur yang Terdaftar di Bursa Efek Indonesia (BEI). Journal of Accounting Fakultas Ekonomika dan Bisnis, Universitas Diponegoro. Semarang.

Skousen, Christopher J; Kevin R. Smith dan Charlotte J. Wright . 2009. "Detecting And Predicting Financial Statement Fraud: The Effectiveness of The Fraud Traingle and SAS No. 99." http://ssrn.com/abstract=1295494. 12 Desember 2015.

Spathis, T. Charalambos. 2002. "Detecting False Financial Statements Using Published Data: SomeEvidence from Greece”. Managerial Auditing Journal, Vol.17.

Statistik Pasar Modal Syariah. Direktorat Pasar Modal Syariah - Otoritas Jasa Keuangan.

Tessa, Chyntia G.,Puji Harto.(2016)" Fraudulent Financial Reporting: Pengujian Teori Fraud Pentagon Pada Sektor Keuangan Dan Perbankan Di Indonesia". Simposium Nasional Akuntansi XIX, Lampung. 
Wolfe, David T and Dana R. Hermanson. 2004. "The Fraud Diamond : Considering the Four Elements of Fraud”. CPA Journal. $74.12: 38-42$

www.idx.co.id

Yesiariani, Merissa dan Isti Rahayu (2016) “Analisis Fraud Diamond Dalam Mendeteksi Financial Statement Fraud (Studi Empiris pada Perusahaan LQ-45 yang Terdaftar di Bursa Efek Indonesia Tahun 2010 - 2014)”. Simposium Nasional Akuntansi XIX, Lampung.

Yusof, Mohamed. K., Ahmad Khair A.H. and Jon Simon, et al. 2015. "Fraudulent Listed Companies”. The Macrotheme Review 4(3), Spring. 